\title{
COMMENT ON THE DISCUSSION ARTICLE BY AASE AND PERSSON
}

I applaud the article as it is exactly the type of reaction to my editorial in Astin Bulletin 32(2) that I hoped to provoke. Of course Aase and Persson's contribution is much more academic in style than mine which is more journalistic.

To my understanding there are three important messages on which every reader of their article should reflect.

Message 1: The kind of NUMeraire based Actuarial Teaching (NUMAT) which I have advocated has been offered since the beginning of the 90ties at the Norwegian School of Economics and Business Administration in Bergen and there exists even an elementary textbook [1] covering that subject (unfortunately only in Norwegian language).

Message 2: The structure of Zero Coupon Prices needed is not so easy to get as my editorial suggested ("You can look it up in the Financial Part of your daily newspaper"). Of course my wording was a tribute to the journalistic style. To talk as a scientist I would like to mention that in a recent Diploma Thesis at ETH [2] we have interpolated from LIBOR Forward Short Rates and from SWAP Rates to get the Zero Coupon Prices. Obviously in any real world implementation there is the necessity for modelling the market prices and the daily newspaper does not suffice.

Message 3: Prices calculated by NUMAT are indeed volatile! This lesson should be learned by every actuary. It means that the products sold by Life Insurers have substantially varying market value.

As hinted in my editorial I would see the practical role of NUMAT for calculating Embedded Value rather than for calculating Premiums. I take again an example from the above mentioned Diploma Thesis:

Take an Endowment Policy ( $x=50, n=5$, sum insured 50000 CHF). According to the Swiss Table EKM 95 the yearly premium amounts to 9375.21 CHF. The value of the initial reserve by NUMAT amounts to

- CHF 2325.45 based on the Zero Coupon Structure of May 2000,

- CHF 11.67 based on the Zero Coupon Structure of November 2002.

As the classical initial net reserve is nil you get the Economic Value by changing the sign. Hence your pretty Embedded Value in May 2000 has disappeared in November 2002.

This is again a lesson to be learned by everybody who boosts with the "wonderful Embedded Value" in her/his Life Portfolio! Embedded Value is extremely volatile and needs to be monitored continuously. 
The last message is my own:

Message 4: I hope to hear from other colleagues that they are already offering Numeraire based Actuarial Teaching. So far the signal from Bergen is the only one that I have received. Clearly, there are research papers where the economic value of insurance products is discussed and explicitly calculated. The point which I tried to make in my editorial was however: NUMAT should be part of the educational curriculum of every actuary. We academics are challenged to get the fundamental way of thinking over to the profession!

\section{REFERENCES}

[1] K.K. AASE. Anvendt sannsynlighetsteorie: Forsikring Matematik, Carrelen Akademisk Forlag, Oslo, Norge 1996.

[2] G. Baumgartner. Fair Value für Lebensversicherungen. Diploma Thesis, ETH Zürich, 2003.

HANS BÜHLMANN

ETH Zürich 